\title{
Javaslat talajosztályozási rendszerünk megújítására: alapelvek, módszerek, alapegységek
}

\author{
${ }^{1}$ MichÉLi Erika, ${ }^{1}$ Fuchs Márta, ${ }^{1}$ LÁNG Vince, ${ }^{1}$ SzEGI Tamás, \\ ${ }^{2}$ Dobos Endre és ${ }^{3}$ SzABÓNÉ KeLE Gabriella \\ ${ }^{1}$ SZIE MKK Talajtani és Agrokémiai Tanszék, Gödöllő; ${ }^{2}$ Miskolci Egyetem, Földrajz- \\ Geoinfomatikai Intézet, Miskolc és ${ }^{3}$ Fejér Megyei Kormányhivatal, Növény- és Talaj- \\ védelmi Igazgatóság, Velence
}

\section{Bevezetés}

A talajosztályozási rendszerekkel szemben támasztott igények és elvárások lényegesen megváltoztak az utóbbi évtizedekben. A felvételezési és vizsgálati módszerekben történt fejlődés jelentős mennyiségü új adatot, információt eredményezett talajaink tulajdonságairól és kiterjedéséről. Az adatok tárolásában és feldolgozásában rendelkezésre álló modern eszközök és módszerek pedig új összefüggések feltárását és értelmezését teszik lehetővé. Mindezzel párhuzamosan a digitális technológiák robbanásszerü elterjedése egyre inkább a számszerűen meghatározható, és globálisan összevethető adatigényt támasztott a talajtanban, megszabva ezzel a talajosztályozási rendszerek fejlődésének irányát is.

Napjaink általánosan elfogadott nemzetközi talajosztályozási rendszerei, mint az US Soil Taxonomy (SOIL SURVEY STAFF, 1999), és a nemzetközi talajkorrelációs rendszer, a World Reference Base for Soil Resources (IUSS WORKING GROUP WRB, 2006) a szigorú definíciókon és számszerü határértékeken nyugvó, úgy nevezett diagnosztikus szemléleten alapulnak. Hasonló megközelítés jellemzi a legtöbb megújult nemzeti (pl. a cseh, az orosz, a román vagy a kínai) rendszert is, melyek a diagnosztikai szemléletre történő áttéréskor gyakran kölcsönöztek különbözö definíciókat, határértékeket és elnevezéséket a nemzetközi rendszerektől, megkönnyítve a további kommunikációt és az adatcserét.

Jelenlegi, genetikai alapokon nyugvó talajosztályozási rendszerünk (SzABOLCS, 1966; STEFANOVITS, 1972; JASSÓ, 1989) évtizedeken keresztül jól szolgálta a hazai igényeket. A genetikai szemlélet jellegéből adódóan azonban az osztályozás definíciói és döntési szabályai sok szubjektív elemet tartalmaznak, amelyek megnehezítik a talajok egyértelmü elkülönítését, elnevezését és nemzetközi megfeleltetését (MICHÉLI et al., 2006). A globális és európai változások hatására időszerüvé vált hazai rendszerünk felülvizsgálata, megújítása, valamint megfeleltetése a nemzetközi ajánlásoknak, elvárásoknak.

Postai cím: MICHÉLI ERIKA, SZIE MKK Talajtani és Agrokémiai Tanszék, 2103 Gödöllö, Páter Károly u. 1.E-mail: Micheli.Erika@mkk.szie.hu. 
A megújítási munkálatok során célunk, a magyar talajtani hagyományok megőrzése mellett, a modern, diagnosztikus szemlélet bevezetése talajaink egyértelmü elkülöníthetősége, osztályokba sorolása érdekében, a szélesebb alkalmazói kör igényeinek szolgálata és a nemzetközi megfeleltetés biztositása. Jelen dolgozatunkkal bevezetjük és vitára bocsátjuk a megújítás módszereit és átfogó alapelemeit. Az osztályozó kulcs és az egyes típusok, - a kapcsolódó definíciókkal - terjedelmi okokból az elkövetkező folyóiratszámokban kerülnek részletes bemutatásra.

\section{Anyag és módszer}

A kiindulásként használt, jelenleg érvényes talajgenetikai alapokon nyugvó osztályozási rendszer egységei mellett, munkánk alapjául a hazai elméleti-, és gyakorlati talajtani tudományban felhalmozott tudásanyag, és nagy mennyiségű talajadat szolgált. Az osztályozási egységek definíciói, leírása a STEFANOVITS (1963, 1972), MÁTÉ (1960), SZABOLCS (1966) illetve JASSÓ és munkatársai $(1987,1988)$ által összeállított kiadványok alapján kerültek áttekintésre.

Nemzetközi standardként a „FAO útmutató a talajok leírásához” c. kiadványa (FAO, 2006), a Világ Talaj Referencia Bázis (WRB WG, 2006; 2014) és az UDSA Talajosztályozási rendszere (SOIL SURVEY STAFF, 2009) szolgált.

A megújítás során megvizsgáltuk a genetikai osztályozás alapját képező talajképző folyamatok, és a diagnosztikus szemlélet egységeinek összefüggéseit, majd az egyes folyamatokat diagnosztikus kategóriákhoz kapcsoltuk (MICHÉLI, 2011). Meghatároztuk a nemzetközi rendszerekböl a hazai környezeti viszonyok között előforduló diagnosztikus egységek szükített körét, amelyeket további, numerikus vizsgálatoknak vetettünk alá.

A numerikus vizsgálatokhoz felhasznált talajadatokat elsősorban a Talajvédelmi és Információs Monitoring Rendszer (TIM) adatbázisa (VÁRALlYAY, 2010), továbbá saját terepi és laboratóriumi vizsgálati adatok biztosították.

A TIM adatbázist a numerikus vizsgálatokat megelőzően minőségellenőrzésnek vetettük alá, a szelvényadatok hibáinak (egymásnak ellentmondó adatpárok, folytonossági hiányok, hibás besorolások stb.) kiszürése érdekében. A minőségellenőrzés után alapstatisztikai vizsgálatokat (pl. átlag, súlyozott átlag, szórás), valamint egyéb módszereket is alkalmaztunk, mint a taxonómiai távolság számítás (Euklidészi és Mahalabonis-i távolság), a főkomponens- és klaszteranalízis (LÁNG, 2013). Tanulmányoztuk továbbá a szelvények matematikai-, és statisztikai eloszlását, valamint az egyes osztályozási egységek közötti összefüggéseket.

A TIM adatbázisában tárolt archív adatokat, mint például a genetikai szinteket és tulajdonságokat automatizált algoritmus rendszerrel konvertáltuk a javasolt rendszer definícióit követve, az abban meghatározott egységekre (WALTNER et al., 2012; LÁNG, 2013b). Az osztályozási egységek hasonlóságát, ill. különbözőségét, és nemzetközi korrelációját numerikus alapon, az ún. taxonómiai rokonság számítással értelmeztük (LÁNG, 2013b). Az elméleti összefüggések elemzésének, azaz a „koncepció" alapú megközelítésnek, a definíciókban megadott tulajdonságok és folya- 
matok képezték alapját. A felvett és mért talajadatokból számított taxonómiai távolságokhoz az egyes osztályozási egységekhez rendelt paraméterek centroid értékeit használtuk. E módszerek részletei a FUCHS és munkatársai (2011) és LÁNG és munkatársai $(2010,2013)$ munkáiban találhatók.

A javasolt hazai talajosztályozási rendszer típusait a rendszer osztályozó kulcsa alapján készített számítógépes algoritmusokkal származtattuk. Az osztályozó algoritmus a laboratóriumi adatoknak ad prioritást, azok nagyobb megbízhatósága és az akkreditált laboratóriumi mérése miatt. Az osztályozó algoritmus nagymértékben követi a definíciókat, köszönhetően a jól definiált, egyszerü diagnosztikus rendszernek (LÁNG, 2013).

\section{Eredmények}

Mind a koncepció-, mind a számszerü adatokon nyugvó numerikus vizsgálatok nagymértékben elősegítették a talajképződés eredményeképpen kialakuló talajtulajdonságok megjelenésének értelmezését, és a különböző talajtípusok elkülönítésében játszott szerepük megértését. Eredményeink jelentősen hozzájárultak a diagnosztikus kategóriák, valamint az új osztályozási egységek meghatározásához is (FUCHS et al., 2011; MiCHÉLI, 2011; LÁNG, 2013b).

Vizsgálataink alapján és hazánk környezeti viszonyainak figyelembevételével 14 db, szigorúan definiált és számszerü kritériumokon nyugvó diagnosztikus kategóriát (diagnosztikus talajszintet, talajtulajdonságot és talajanyagot) határoztunk meg, melyek valamennyi egységnél azonos értelmezést kapnak (1. táblázat). A definíciók a „www.talaj.hu” honlapon (MICHÉLI et. al., 2015) találhatók, részletes tárgyalásukat pedig a talajtípusokhoz kapcsolódóan a későbbiekben tervezzük.

\section{1. táblázat}

14 szigorúan definiált és számszerü kritériumokon nyugvó diagnosztikus kategória a megújuló hazai talajosztályozási rendszerben

\begin{tabular}{|l|l|}
\hline & Agyagfelhalmozódási szint \\
& Duzzadó szint \\
& Cambic szint \\
& Humuszos szint \\
& Karbonátfelhalmozódásos szint \\
\hline & Szolonyeces felhalmozódási szint \\
& Szoloncsákos felhalmozódási szint \\
& Vaskiválásos szint \\
& Talajvízglejes színmintázat \\
& Pangóvízglejes színmintázat \\
\hline \multirow{2}{*}{ c) Diagnosztikus talajtulajdonságok talajszintek } & Összefüggó kemény közet \\
& Reduktív viszonyok \\
\hline
\end{tabular}


A diagnosztikus kategóriák definíciói nem megegyezőek, gyakran egyszerübbek (kevesebb kritériumot, ill. al-kritériumot tartalmazóak), de a WRB vonatkozó kategóriáival megfeleltethetőek. Részletes leírásukat a későbbiekben tervezzük.

Az osztályozás alapegységeit a talajtípusok alkotják. Jelenlegi rendszerünk azon talajtípusai, melyek a numerikus számítások alapján nagymértékben különböznek, a megújított rendszerben is meghatározásra kerültek, míg azon talajtípusok, melyek nagy taxonómiai rokonságot - hasonlóságot - mutató talajtípusokat azonban az új rendszerben összevontuk (2. táblázat).

\section{2. táblázat}

A jelenlegi, és a megújított osztályozási rendszer talajtípusai (angol elnevezések zárójelben), a megújítás során levont konklúziók, a korszerüsítés rövid összefoglalása a diagnosztikus definíciók alapjai, valamint az új egységek WRB Referencia csoportokkal (RSG) való megfeleltetése

\begin{tabular}{|c|c|c|c|}
\hline $\begin{array}{l}\text { (1) } \\
\text { Talajtípus neve a ha- } \\
\text { gyományos, genetikai } \\
\text { rendszerben }\end{array}$ & $\begin{array}{c}\text { (2) } \\
\text { Taxon megváltoztatásá- } \\
\text { nak szükségessége, és a } \\
\text { diagnosztikus definíció } \\
\text { alapja }\end{array}$ & $\begin{array}{l}\text { Talajtípus neve a } \\
\text { megújított rend- } \\
\text { szerben }\end{array}$ & $\begin{array}{l}(4) \\
\text { WRB Refe- } \\
\text { rencia csoport } \\
\quad(\text { RSG) }\end{array}$ \\
\hline $\begin{array}{l}\text { Mohaláp } \\
\text { (Sphagnum peats) }\end{array}$ & \multirow{3}{*}{$\begin{array}{l}\text { Határozottan elkülönülő } \\
\text { talajok, } \\
\text { szigorúbb definíció a } \\
\text { szervesanyag -tartalomra, } \\
\text { a vastagsági és mélységi } \\
\text { követelményekre }\end{array}$} & \multirow[t]{3}{*}{$\begin{array}{l}\text { Láptalaj } \\
\text { (Peat soils) }\end{array}$} & \multirow[t]{3}{*}{ Histosols } \\
\hline $\begin{array}{l}\text { Rétláp (Meadow peat } \\
\text { soils) }\end{array}$ & & & \\
\hline $\begin{array}{l}\text { Lecsapolt és telkesített } \\
\text { rétláp (Drained peats) }\end{array}$ & & & \\
\hline $\begin{array}{l}\text { Köves sziklás váztalaj } \\
\text { (Stony skeletal soils) }\end{array}$ & $\begin{array}{l}\text { Határozottan elkülönülő } \\
\text { talajok, } \\
\text { szigorúbb definíció a } \\
\text { mélységi követelmények- } \\
\text { re }\end{array}$ & $\begin{array}{l}\text { Köves sziklás } \\
\text { váztalaj } \\
\text { (Shallow rocky } \\
\text { soils) }\end{array}$ & Leptosols \\
\hline $\begin{array}{l}\text { Földeskopár } \\
\text { (Barren earth) }\end{array}$ & $\begin{array}{l}\text { Határozottan elkülönülő } \\
\text { („,egyéb”) talajok, nincs } \\
\text { diagnosztikai követel- } \\
\text { mény }\end{array}$ & $\begin{array}{l}\text { Földeskopár } \\
\text { (Barren earth) }\end{array}$ & Regosols \\
\hline $\begin{array}{l}\text { Futóhomok } \\
\text { (Shifting sands) }\end{array}$ & \multirow{2}{*}{$\begin{array}{l}\text { Határozottan } \\
\text { elkülönülő talajok, } \\
\text { szigorúbb definíció a } \\
\text { homoktartalomra }\end{array}$} & \multirow[t]{2}{*}{$\begin{array}{l}\text { Homoktalaj } \\
\text { (Sandy soils) }\end{array}$} & \multirow[t]{2}{*}{ Arenosols } \\
\hline $\begin{array}{l}\text { Humuszos homok } \\
\text { (Humic sandy soils) }\end{array}$ & & & \\
\hline $\begin{array}{l}\text { Humuszkarbonát talaj } \\
\text { (Humus-carbonate } \\
\text { soils) }\end{array}$ & $\begin{array}{l}\text { Határozottan } \\
\text { elkülönülö talajok, } \\
\text { szigorúbb definíció a } \\
\mathrm{CaCO}_{3} \text {-tartalomra, a } \\
\text { vastagsági és mélységi } \\
\text { követelményekre }\end{array}$ & $\begin{array}{l}\text { Karbonát talaj } \\
\text { (Carbonate soils) }\end{array}$ & Calcisols \\
\hline
\end{tabular}


2. táblázat folytatása

\begin{tabular}{|c|c|c|c|}
\hline $\begin{array}{l}\text { Talajtípus neve a ha- } \\
\text { gyományos, genetikai } \\
\text { rendszerben }\end{array}$ & $\begin{array}{l}\text { (2) } \\
\text { Taxon megváltoztatá- } \\
\text { sának szükségessége, } \\
\text { és a diagnosztikus } \\
\text { definíció alapja }\end{array}$ & $\begin{array}{l}\text { Talajtípus neve a } \\
\text { megújított rend- } \\
\text { szerben }\end{array}$ & $\begin{array}{l}(4) \\
\text { WRB Refe- } \\
\text { rencia csoport } \\
\text { (RSG) }\end{array}$ \\
\hline $\begin{array}{l}\text { Kavicsos váztalaj } \\
\text { (Gravelly skeletal } \\
\text { soils) }\end{array}$ & \multirow{4}{*}{$\begin{array}{l}\text { Határozottan } \\
\text { elkülönülő talajok, } \\
\text { kőzettani különbsé- } \\
\text { gektől való eltekintés, } \\
\text { szigorúbb definíció a } \\
\text { mélységi és durva } \\
\text { vázrész tartalom köve- } \\
\text { telményekre }\end{array}$} & \multirow[t]{4}{*}{$\begin{array}{l}\text { Közethatású talaj } \\
\text { (Lithogenic soils) }\end{array}$} & \multirow[t]{4}{*}{ Leptosols } \\
\hline Rendzina (Rendzinas) & & & \\
\hline $\begin{array}{l}\text { Fekete nyirok } \\
\text { (Erubase) }\end{array}$ & & & \\
\hline Ranker (Ranker soils) & & & \\
\hline $\begin{array}{l}\text { Mészlepedékes cser- } \\
\text { nozjom } \\
\text { (Pseudomyceliar } \\
\text { chernozems) }\end{array}$ & \multirow{5}{*}{$\begin{array}{l}\text { Határozottan } \\
\text { elkülönülö talajok, } \\
\text { szigorúbb definíció a } \\
\text { szervesanyag- és } \\
\mathrm{CaCO}_{3} \text {-tartalomra, } \\
\text { színre, vastagságra és } \\
\text { bázistelítettségre }\end{array}$} & \multirow[t]{5}{*}{$\begin{array}{l}\text { Mezőségi talaj } \\
\text { (Steppe soils) }\end{array}$} & \multirow[t]{5}{*}{$\begin{array}{l}\text { Chernozems, } \\
\text { Kastanozems, } \\
\text { Phaeozems }\end{array}$} \\
\hline $\begin{array}{l}\text { Kilúgzott csernozjom } \\
\text { (Leached chernozems) }\end{array}$ & & & \\
\hline $\begin{array}{l}\text { Réti csernozjom } \\
\text { (Meadow chernozems) }\end{array}$ & & & \\
\hline $\begin{array}{l}\text { Öntés csernozjom } \\
\text { (Alluvial chernozems) }\end{array}$ & & & \\
\hline $\begin{array}{l}\text { Csernozjom barna } \\
\text { erdőtalaj (Chernozem } \\
\text { brown forest soils) }\end{array}$ & & & \\
\hline $\begin{array}{l}\text { Barnaföld (Brown } \\
\text { earths) }\end{array}$ & $\begin{array}{l}\text { Határozottan elkülönü- } \\
\text { lő talajok, } \\
\text { szigorúbb definíció a } \\
\text { talajszerkezetre, színre } \\
\text { és } \mathrm{CaCO}_{3} \text { megjelenés- } \\
\text { re }\end{array}$ & $\begin{array}{l}\text { Barnaföld } \\
\text { (Brown earths) }\end{array}$ & Cambisols \\
\hline $\begin{array}{l}\text { Savanyú nem podzolos } \\
\text { erdőtalaj (Acidic, non- } \\
\text { podzolic brown forest } \\
\text { soils) }\end{array}$ & $\begin{array}{l}\text { Összevonva a } \\
\text { Barnaföldekkel }\end{array}$ & & \\
\hline $\begin{array}{l}\text { Agyagbemosódásos } \\
\text { erdőtalaj (Brown forest } \\
\text { soils with clay } \\
\text { illuviation) }\end{array}$ & \multirow{2}{*}{$\begin{array}{l}\text { Határozottan } \\
\text { elkülönülö talajok, } \\
\text { szigorúbb definíció az } \\
\text { agyagtartalomra és } \\
\text { agyagnövekedésre, } \\
\text { vastagsági és mélységi } \\
\text { követelményekre }\end{array}$} & \multirow[t]{2}{*}{$\begin{array}{l}\text { Agyagbemosódásos } \\
\text { talaj } \\
\text { (Clay accumulation } \\
\text { soils) }\end{array}$} & \multirow[t]{2}{*}{ Luvisols } \\
\hline $\begin{array}{l}\text { Podzolos barna erdőta- } \\
\text { laj (Podzolic brown } \\
\text { forest soils) }\end{array}$ & & & \\
\hline
\end{tabular}


2. táblázat folytatása

\begin{tabular}{|c|c|c|c|}
\hline $\begin{array}{l}\text { Talajtípus neve a } \\
\text { hagyományos, geneti- } \\
\text { kai rendszerben }\end{array}$ & $\begin{array}{l}\text { (2) } \\
\text { Taxon megváltoztatá- } \\
\text { sának szükségessége, } \\
\text { és a diagnosztikus } \\
\text { definíció alapja }\end{array}$ & $\begin{array}{l}\text { Talajtípus neve a } \\
\text { megújított rend- } \\
\text { szerben }\end{array}$ & $\begin{array}{l}\text { (4) } \\
\text { WRB Referen- } \\
\text { cia csoport } \\
\text { (RSG) }\end{array}$ \\
\hline $\begin{array}{l}\text { Pangóvizes barna } \\
\text { erdőtalaj (Stagnant } \\
\text { brown forest soils) }\end{array}$ & \multirow{2}{*}{$\begin{array}{l}\text { Határozottan } \\
\text { elkülönülö talajok, } \\
\text { szigorúbb definíció az } \\
\text { agyagtartalomra és } \\
\text { agyagnövekedésre, } \\
\text { vastagsági és mélységi } \\
\text { követelményekre }\end{array}$} & \multirow{2}{*}{$\begin{array}{l}\text { Agyagbemosódásos } \\
\text { talaj } \\
\text { (Clay accumulation } \\
\text { soils) }\end{array}$} & \multirow[t]{2}{*}{ Luvisols } \\
\hline $\begin{array}{l}\text { Kovárványos barna } \\
\text { erdőtalaj (Banded } \\
\text { brown forest soils) }\end{array}$ & & & \\
\hline $\begin{array}{l}\text { Szoloncsák } \\
\text { (Solonchaks) }\end{array}$ & $\begin{array}{l}\text { Határozottan } \\
\text { elkülönülő talajok, } \\
\text { szigorúbb definíció az } \\
\text { elektromos vezetőké- } \\
\text { pességre, pH-ra, vas- } \\
\text { tagsági és mélységi } \\
\text { követelményekre }\end{array}$ & $\begin{array}{l}\text { Szoloncsák } \\
\text { (Solonchak soils) }\end{array}$ & Solonchaks \\
\hline $\begin{array}{l}\text { Réti szolonyec } \\
\text { (Meadow solonetz } \\
\text { soils) }\end{array}$ & $\begin{array}{l}\text { Határozottan elkülönü- } \\
\text { lő talajok, } \\
\text { szigorúbb definíció a } \\
\text { Na- (és Mg-) tartalom- } \\
\text { ra, és talajszerkezet } \\
\text { követelményekre }\end{array}$ & $\begin{array}{l}\text { Szolonyec } \\
\text { (Solonetz soils) }\end{array}$ & Solonetz \\
\hline $\begin{array}{l}\text { Szoloncsák-szolonyec } \\
\text { (Solonchak- } \\
\text { solonetzes) }\end{array}$ & $\begin{array}{l}\text { Összevonva a } \\
\text { Szoloncsákokkal }\end{array}$ & $\begin{array}{l}\text { Szoloncsák } \\
\text { (Solonchak soils) }\end{array}$ & Solonchaks \\
\hline $\begin{array}{l}\text { Másodlagosan elszi- } \\
\text { kesedett talajok } \\
\text { (Secondary salt } \\
\text { affected soils) }\end{array}$ & $\begin{array}{l}\text { Összevonva a } \\
\text { Szoloncsákokkal / } \\
\text { Szolonyecekkel }\end{array}$ & $\begin{array}{l}\text { Szoloncsák vagy } \\
\text { Szolonyec } \\
\text { (Solonchak or } \\
\text { Solonetz soils) } \\
\end{array}$ & $\begin{array}{l}\text { Solonchaks } \\
\text { vagy Solonetz }\end{array}$ \\
\hline $\begin{array}{l}\text { Sztyeppesedő réti } \\
\text { szolonyec (Steppe } \\
\text { meadow solonetz } \\
\text { soils) }\end{array}$ & $\begin{array}{l}\text { Összevonva a Mezősé- } \\
\text { gi / Duzzadó agyagtala- } \\
\text { jokkal }\end{array}$ & $\begin{array}{l}\text { Mezőségi vagy } \\
\text { Duzzadó agyagtalaj } \\
\text { (Steppe soils or } \\
\text { Swelling clay soils) }\end{array}$ & $\begin{array}{l}\text { Chernozems, } \\
\text { Kastanozems, } \\
\text { Phaeozems } \\
\text { Vertisols vagy } \\
\text { Solonetz }\end{array}$ \\
\hline $\begin{array}{l}\text { Szoloncsákos réti talaj } \\
\text { (Solonchak meadow } \\
\text { soils) }\end{array}$ & \multirow[t]{2}{*}{$\begin{array}{l}\text { Összevonva a Réti / } \\
\text { Duzzadó agyagtalajok- } \\
\text { kal }\end{array}$} & \multirow{2}{*}{$\begin{array}{l}\text { Réti vagy Duzzadó } \\
\text { agyagtalaj } \\
\text { (Meadow soils or } \\
\text { Swelling clay soils) }\end{array}$} & \multirow[t]{2}{*}{$\begin{array}{l}\text { Gleysols vagy } \\
\text { Vertisols }\end{array}$} \\
\hline $\begin{array}{l}\text { Szolonyeces réti talaj } \\
\text { (Solonetzic meadow } \\
\text { soil) }\end{array}$ & & & \\
\hline
\end{tabular}


2. táblázat folytatása

\begin{tabular}{|c|c|c|c|}
\hline $\begin{array}{l}\text { Talajtípus neve a } \\
\text { hagyományos, gene- } \\
\text { tikai rendszerben }\end{array}$ & $\begin{array}{c}\text { (2) } \\
\text { Taxon megváltoztatásá- } \\
\text { nak szükségessége, és a } \\
\text { diagnosztikus definíció } \\
\text { alapja }\end{array}$ & $\begin{array}{l}\text { (3) } \\
\text { Talajtípus neve a } \\
\text { megújított rend- } \\
\text { szerben }\end{array}$ & $\begin{array}{l}(4) \\
\text { WRB Refe- } \\
\text { rencia csoport } \\
\text { (RSG) }\end{array}$ \\
\hline $\begin{array}{l}\text { Típusos réti talaj } \\
\text { (Typic meadow soils) }\end{array}$ & $\begin{array}{l}\text { Határozottan } \\
\text { elkülönülö talajok, } \\
\text { szigorúbb definíció a } \\
\text { reduktív és glejes tulaj- } \\
\text { donságokra, a megjele- } \\
\text { nésre és mélységi köve- } \\
\text { telményekre }\end{array}$ & $\begin{array}{l}\text { Réti talaj } \\
\text { (Meadow soils) }\end{array}$ & Gleysols \\
\hline $\begin{array}{l}\text { Lápos réti talaj } \\
\text { (Peaty meadow soil) }\end{array}$ & $\begin{array}{l}\text { Összevonva a Mezőségi } \\
\text { talajokkal }\end{array}$ & $\begin{array}{l}\text { Mezőségi talaj } \\
\text { (Steppe soils) }\end{array}$ & $\begin{array}{l}\text { Chernozems, } \\
\text { Kastanozems, } \\
\text { Phaeozems }\end{array}$ \\
\hline $\begin{array}{l}\text { Csernozjom réti talaj } \\
\text { (Chernozem meadow } \\
\text { soils) }\end{array}$ & $\begin{array}{l}\text { Összevonva a Mezőségi } \\
\text { / Duzzadó agyagtala- } \\
\text { jokkal }\end{array}$ & $\begin{array}{l}\text { Mezőségi vagy } \\
\text { Duzzadó agyagtalaj } \\
\text { (Steppe soils or } \\
\text { Swelling clay soils) }\end{array}$ & $\begin{array}{l}\text { Chernozems, } \\
\text { Kastanozems, } \\
\text { Phaeozems } \\
\text { vagy Vertisols }\end{array}$ \\
\hline $\begin{array}{l}\text { Öntés réti talaj } \\
\text { (Alluvial meadow } \\
\text { soils) }\end{array}$ & $\begin{array}{l}\text { Összevonva a Mezőségi } \\
\text { / Duzzadó agyag / Hor- } \\
\text { daléktalajokkal }\end{array}$ & $\begin{array}{l}\text { Mezőségi vagy } \\
\text { Duzzadó agyagtalaj } \\
\text { vagy Hordaléktalaj } \\
\text { (Steppe soils or } \\
\text { Swelling clay soils } \\
\text { or Sediment soils) }\end{array}$ & $\begin{array}{l}\text { Chernozems, } \\
\text { Kastanozems, } \\
\text { Phaeozems } \\
\text { vagy Vertisols } \\
\text { vagy } \\
\text { Fluvisols }\end{array}$ \\
\hline $\begin{array}{l}\text { Mocsári és ártéri } \\
\text { erdők talajai (Soils of } \\
\text { swampy forests) }\end{array}$ & $\begin{array}{l}\text { Összevonva a Réti } \\
\text { talajokkal }\end{array}$ & $\begin{array}{l}\text { Réti talaj } \\
\text { (Meadow soils) }\end{array}$ & Gleysols \\
\hline $\begin{array}{l}\text { Nyers öntéstalaj } \\
\text { (Raw alluvial soils) }\end{array}$ & \multirow{3}{*}{$\begin{array}{l}\text { Határozottan } \\
\text { elkülönülő talajok, } \\
\text { szigorúbb definíció a } \\
\text { rétegzettségi követel- } \\
\text { ményekre }\end{array}$} & \multirow[t]{3}{*}{$\begin{array}{l}\text { Hordaléktalaj } \\
\text { (Sediment soils) }\end{array}$} & \multirow{3}{*}{$\begin{array}{l}\text { Fluvisols és } \\
\text { Colluvic } \\
\text { Regosols }\end{array}$} \\
\hline $\begin{array}{l}\text { Humuszos öntéstalaj } \\
\text { (Humic alluvial soils) }\end{array}$ & & & \\
\hline $\begin{array}{l}\text { Lejtőhordalék talaj } \\
\text { (Soils of slope } \\
\text { sediments) }\end{array}$ & & & \\
\hline $\begin{array}{l}\text { ÚJ - az előző rend- } \\
\text { szerben nem definiált } \\
\text { talajtípus }\end{array}$ & $\begin{array}{l}\text { Az előző rendszerben } \\
\text { nem definiált, új talajtí- } \\
\text { pus, definíció az agyag- } \\
\text { tartalom, morfológia, } \\
\text { vastagsági és mélységi } \\
\text { követelményekre }\end{array}$ & $\begin{array}{l}\text { Duzzadó agyagtalaj } \\
\text { (Swelling clay } \\
\text { soils) }\end{array}$ & Vertisols \\
\hline $\begin{array}{l}\text { ÚJ - az előző rend- } \\
\text { szerben nem definiált } \\
\text { talajtípus }\end{array}$ & $\begin{array}{l}\text { Új talajtípus, definíció } \\
\text { az ember által létreho- } \\
\text { zott anyagok megjele- } \\
\text { nésére }\end{array}$ & $\begin{array}{l}\text { Antropogén talaj } \\
\text { (Anthropogenic } \\
\text { soils) }\end{array}$ & $\begin{array}{l}\text { Anthrosols és } \\
\text { Technosols }\end{array}$ \\
\hline
\end{tabular}


Mindezek alapján a megújított talajosztályozási rendszerben 15 talajtípust határoztunk meg. Elkülönítésük a diagnosztikus kategóriák alapján határozó kulcs segítségével történik. Megfogalmazásuk a határozó kulcsban általános leírásból és osztályozási követelményekből tevődik össze.

$\mathrm{Az}$ osztályozás alacsonyabb szintjein $28 \mathrm{db}$ altípust és $14 \mathrm{db}$ változati tulajdonságot határoztunk meg. Ezek további fontos (átmeneti, kémiai, fizikai és genetikai) talajtulajdonságok jellemzésére szolgálnak. A diagnosztikus kategóriákhoz hasonlóan valamennyi osztályozási egységnél azonos értelmezést kapnak.

$\mathrm{Az}$ altípus és változati tulajdonságok mélységi megjelenésének, kifejezettségének és a határértéknél nagyobb vastagsági megjelenésének jelzésére ún. pontosító jelzők használhatók (3. táblázat).

Az altípus és változati tulajdonságok bemutatását szintén a későbbiekben tervezzük.

\section{3. táblázat}

A megújított osztályozási rendszer alacsonyabb szintjein javasolt altípus és változati tulajdonságok, valamint pontosító jelzők

\begin{tabular}{|l|l|}
\hline & Agyagbemosódásos \\
& Cementált \\
& Duzzadó \\
& Fekete (csak Mezőségi talajokban) \\
Gipszes \\
& Glejes (réti) \\
& Humuszos \\
& Karbonátos \\
& Karbonát-szulfátos \\
Altípus tulajdonságok & Karbonát-kloridos \\
& Kérges \\
& Kotús (csak Láptalajokban) \\
& Kovárványos \\
& Kőzethatáros \\
& Lecsapolt (csak Láptalajokban) \\
Mészlepedékes (csak Mezőségi talajokban) \\
Mohatózeges (csak Láptalajokban) \\
Öntés \\
Pangóvizes \\
Podzolos \\
Rostostőzeges (csak Láptalajokban)
\end{tabular}


3. táblázat folytatása

\begin{tabular}{|c|l|}
\hline \multirow{4}{*}{ Altípus tulajdonságok } & Száraztőzeges \\
& Szódás (nátriumos) \\
& Szologyos \\
& Szoloncsákos \\
& Típusos \\
& Tőzeges \\
& Vegyes tőzeges (csak Láptalajokban) \\
\hline Változati & Eltemetett \\
& Fakó \\
& Hantos \\
& Kavicsos \\
& Közettörmelékes \\
& Lejtőhordalékos \\
& Nyers \\
& Savanyú \\
& Telítetlen \\
& Telített \\
& Többrétegü \\
& Vaskiválásos \\
& Vörös \\
& Mechanikai összetétel szerint (a textúra háromszög \\
& alapján) \\
\hline \multirow{5}{*}{ Pontosító jelzők } & Felszíntöl \\
& Sekély(en) \\
& Középmély(en) \\
& Mély(en) \\
& Erősen \\
& Gyengén \\
\hline & \\
&
\end{tabular}

A megújított rendszer felépítését és működését a „Réti talajok” példáján mutatjuk be:

Eredeti definíció: A réti talajok olyan talajok, melyek keletkezésében az időszakos túlnedvesedés játszik döntő szerepet. A víz hatására beálló levegőtlenség jellegzetes szervesanyag-képződést, az ásványi részek redukcióját váltja ki (JASSÓ et al., 1987, 1988).

Osztályozási problémák: A víztelítettség hatására megjelenő hidromorf bélyegek (redukció, talajvízglejes foltosság) definíciójának, mélységi és mennyiségi megjelenésének határértékekkel történő pontos meghatározása hiányos, amely felveti a más osztályozási egységektől történő objektív elkülönítés, és a nemzetközi osztályozási rendszerekkel való megfeleltetés kérdéseit. 


\begin{tabular}{|c|c|c|c|}
\hline \multirow[t]{2}{*}{1} & szerves anyag $>20 \%,>40 \mathrm{~cm}$ vastagságban & \multirow[t]{2}{*}{ Igen $\rightarrow$} & \multirow[t]{2}{*}{ Láptalajok } \\
\hline & Nem $\downarrow$ & & \\
\hline \multirow[t]{2}{*}{2} & Erőteljes emberi tevékenység & \multirow[t]{2}{*}{ Igen $\rightarrow$} & \multirow[t]{2}{*}{ Antropogén talajok } \\
\hline & Nem $\downarrow$ & & \\
\hline \multirow[t]{2}{*}{3} & Kemény kőzet $<10$ cm-en belül & \multirow[t]{2}{*}{ Igen $\rightarrow$} & \multirow[t]{2}{*}{ Köves sziklás váztalajok } \\
\hline & Nem $\downarrow$ & & \\
\hline \multirow[t]{2}{*}{4} & Kemény kőzet $<25 \mathrm{~cm}$, vagy földesrész $<20 \%$ & \multirow[t]{2}{*}{ Igen $\rightarrow$} & \multirow[t]{2}{*}{ Közethatású talajok } \\
\hline & Nem $\downarrow$ & & \\
\hline \multirow[t]{2}{*}{5} & Na-felhalmozódás $100 \mathrm{~cm}$-en belül & \multirow[t]{2}{*}{ Igen $\rightarrow$} & \multirow[t]{2}{*}{ Szolonyec talajok } \\
\hline & Nem $\downarrow$ & & \\
\hline \multirow[t]{2}{*}{6} & Sófelhalmozódás $50 \mathrm{~cm}$-en belül & \multirow[t]{2}{*}{ Igen $\rightarrow$} & \multirow[t]{2}{*}{ Szoloncsák talajok } \\
\hline & Nem $\downarrow$ & & \\
\hline \multirow[t]{2}{*}{7} & Agyagtartalom $>30 \%$ és duzzadó tulajdonságok & \multirow[t]{2}{*}{ Igen $\rightarrow$} & \multirow[t]{2}{*}{ Duzzadó agyagtalajok } \\
\hline & Nem $\downarrow$ & & \\
\hline \multirow[t]{2}{*}{8} & Talajvízglejes színmintázat $50 \mathrm{~cm}$-en belül & \multirow[t]{2}{*}{ Igen $\rightarrow$} & \multirow[t]{2}{*}{ Réti talajok } \\
\hline & $\mathrm{Nem} \downarrow$ & & \\
\hline 9 & $\mathrm{CaCO}_{3}$-tartalom $>40 \% 50 \mathrm{~cm}$-en belül & \multirow[t]{2}{*}{ Igen $\rightarrow$} & \multirow[t]{2}{*}{ Karbonát talajok } \\
\hline & Nem $\downarrow$ & & \\
\hline \multirow[t]{2}{*}{10} & Szervesanyagban gazdag, bázistelített & \multirow[t]{2}{*}{ Igen $\rightarrow$} & \multirow[t]{2}{*}{ Mezőségi talajok } \\
\hline & Nem $\downarrow$ & & \\
\hline \multirow[t]{2}{*}{11} & Agyagfelhalmozódási talajszint $100 \mathrm{~cm}$-en belül & \multirow[t]{2}{*}{ Igen $\rightarrow$} & \multirow[t]{2}{*}{ Agyagbemosódásos talajok } \\
\hline & Nem $\downarrow$ & & \\
\hline \multirow[t]{2}{*}{12} & Durva textúra $100 \mathrm{~cm}$-es mélységig & Igen $\rightarrow$ & Homoktalajok \\
\hline & Nem $\downarrow$ & & \\
\hline 13 & Gyengén fejlett / fiatal talajok & Igen $\rightarrow$ & Barnaföldek \\
\hline & Nem $\downarrow$ & & \\
\hline 14 & Rétegzett talajanyag $50 \mathrm{~cm}$-en belül & Igen $\rightarrow$ & Hordaléktalajok \\
\hline & Nem $\downarrow$ & & \\
\hline 15 & Más (“egyéb") talajok & Igen $\rightarrow$ & Földes kopárok \\
\hline
\end{tabular}

\section{1. ábra}

Egyszerűsített határozó kulcs a megújított talajosztályozási rendszerhez 
Megújitott definició:

Általános leírás: Más talajok, amelyek kialakulásában jelentős szerepe van a talajvíz okozta időszakos víztelítettségnek. A víztelítettség hatására a talajban reduktív viszonyok, és a vas vegyértékváltásának következtében talajvízglejes szinmintázat alakul ki.

Diagnosztikus kategóriák:

Reduktív viszonyok: A vízzel való állandó, vagy időszakos telítettség hatására kialakuló reduktív viszonyok igazolhatók, amennyiben:

1. $(\mathrm{rH})<20$; vagy

2. Szabad vas $\left(\mathrm{Fe}^{2+}\right)$ kimutatható a friss törési felszíneken $0,2 \%$-os $\alpha-\alpha$ dipyridyl erőteljes vörös színével, vagy

3. (kékes-fekete színü) vas szulfidok vannak jelen, vagy

4. metán van jelen.

Talajvízglejes színmintázat: Időszakos talajvízhatás alatt kialakuló színmintázat, amely:

1. legalább 90\%-a reduktív szürke színnel (Munsell 2.5Y, 5Y, 5G, 5B, vagy Munsell GLEY1, GLEY2) jellemezhetö, és/vagy

2. a vas vegyértékváltásának következtében a szint legalább 5\%-án megjelenik a vörös tarka foltosság (vasszeplök, rozsdafoltok, vas-, ill. vas-mangán borsók) jelenléte, elsősorban gyökérjáratok és egyéb biológiai csatornák, vagy repedések mentén.

Osztályozási követelmények:

A réti talajokban a felszíntől számított $50 \mathrm{~cm}$-en belül:

1. az év egy részében igazolhatók a reduktív viszonyok, és

2. a talajmátrix legalább felében megjelennek a talajvizglejes színmintázat bélyegei.

A javasolt osztályozó kulcs a TIM-ben tárolt adatokon (több mint 1200 db szelvény) jó hatásfokkal, a definíciókat jól követve programozható (LÁNG, 2013). Az osztályozó kulcs a javasolt kulcsban meghatározott struktúrát (1. ábra) követve épült fel. Bizonyos javasolt típusok programozása - így az Antropogén talajok azonban a rendelkezésre álló információk hiánya miatt nem volt kódolható - egy elérhető magyar adatbázis sem tartalmaz jelenleg erre vonatkozó adatokat.

Az egyes talajtípusokra programozott osztályozási funkciók tesztelése jelentősen hozzájárult az osztályozási követelmények, valamint a határozó kulcs végleges kialakításához. A határozó kulcs sorrendjének változtatásával az algoritmusban tanulmányozhatóvá váltak a talajszelvények besorolásának változásai, elősegítve így az osztályozó kulcsban definiált követelmények leegyszerüsítését és ésszerüsítését.

A hagyományos talajosztályozás egységeinek megjelenését, illetve eloszlását az új osztályozási rendszerben későbbi közleményünkben mutatjuk be. 


\section{Összefoglalás}

A jelenlegi, 1960 években kidolgozott genetikus alapokon nyugvó magyar talajosztályozási rendszerünk modernizálására az elmúlt évtizedek hazai tapasztalatai, dokumentált adathalmazai, valamint a nemzetközi standardok és elvárások alapján teszünk javaslatot. Munkánk kiindulási alapja az elődeink által definiált 29 talajképző folyamat, 39 talajtípus, és az azokhoz kapcsolódó tartalmi leírás és vizsgálati adatokból nyert információ. Módszereink az egyszerü elemzések és statisztikai számítások mellet a pedometria módszerére, a taxonómiai távolságszámításra és klaszteranalízisre támaszkodtak.

Eredményeink alapján a jelenlegi hazai talajtípusok egy része jól elkülöníthető, mások pontosabb definícióra szorulnak, vagy egyes esetekben összevonásra kerülhetnek. A nemzetközi gyakorlatban meglévő és hazánkban is jellegzetes típusokat pedig, bevezetésre javaslunk.

A szigorúbb és mind a mélységi, morfológiai és összetételbeli tulajdonságok tekintetében számszerübb meghatározásokon alapuló javasolt struktúra központi egysége az ismertetett 15 talajtípus.

Ezeket a típusokat jól definiált diagnosztikus szintek, talajtulajdonságok és anyagok jelenléte vagy kizárása alapján, hierarchikus és számítógépes osztályozó kulccsal sorolhatók be. Az osztályozás alacsonyabb szintjei, az altípus és a változati tulajdonságok pedig, többszörös választási lehetőségek alapján pontosíthatók. A további talajtípusokat és altípusaik valamint változataikat későbbi közleményekben mutatjuk be.

A munkát az Országos Tudományos Kutatási Alap (OTKA T046513) és az Emberi Erőforrások Minisztériumának Kari Kiválósági Programja (7629-24/2013) támogatta.

Kulcsszavak: talajosztályozás, diagnosztikai szemlélet, numerikus módszerek, taxonómiai kapcsolatok, osztályozó algoritmus

\section{Irodalom}

Fuchs M., WALtner I., Szegi T., LÁNG V. \& MichÉLi E., 2011. A hazai talajtípusok taxonómiai távolsága a képződésüket meghatározó folyamattársulások alapján. Agrokémia és Talajtan. 60. 33-44.

IUSS WORKING GROUP WRB, 2006. World Reference Base for Soil Resources. $2^{\text {nd }}$ ed. World Soil Resources Reports No. 103. FAO. Rome.

IUSS WORKING GROUP WRB, 2014. World Reference Base for Soil Resources. $3 \mathrm{r}^{\mathrm{d}}$ ed. World Soil Resources Reports No. 106. FAO. Rome.

JASSÓ F. (szerk.), 1987. Útmutató a nagyméretarányú országos talajtérképezés végrehajtásához. Melioráció - öntözés és tápanyaggazdálkodás.' 87 melléklet, Agroinform, Budapest. 
JASSÓ F. (szerk.), 1989. Útmutató a nagyméretarányú országos talajtérképezés végrehajtásához. Melioráció - öntözés és talajvédelem.'88 melléklet, Agroinform, Budapest.

LÁNG V., 2013. A hazai talajvédelmet és a nemzetközi megfeleltetést szolgáló adatrendszer fejlesztése. PhD értekezés. Szent István Egyetem. Gödöllő, Hungary.

LÁng, V., Fuchs, M., WAltner, I. \& MichÉli, E., 2010. Taxonomic distance measurements applied for soil correlation. Agrokémia és Talajtan. 59. 57-64.

LÁng, V., Fuchs, M., Waltner, I. \& Michéli, E., 2013. Soil taxonomic distance, a tool for correlation: As exemplified by the Hungarian Brown Forest Soils and related WRB Reference Soil Groups. Geoderma. 192. 269-276.

MÁTÉ F., 1960. Javaslat a hazai réti talajok osztályozására. Agrokémia és Talajtan. 9. $121-131$.

Michéli, E., Fuchs, M., Hegymegi, P. \& Stefanovits, P., 2006. Classification of the major soils of Hungary and their correlation with the World Reference Base for Soil Resources (WRB). Agrokémia és Talajtan. 55. 19-28.

MichÉLi E. et al., 2015. Vitaanyagok a hazai talajosztályozás megújítására. www.talaj.hu/Javaslat- talajosztályozási- rendszerünk- megújítására

MichÉLi E., 2011. A talajképző folyamatok megjelenése a diagnosztikai szemléletű talajosztályozásban. Agrokémia és Talajtan. 60. 17-32.

Minasny, B., McBratney, A. B. \& Hartemink, A. E., 2009. Global pedodiversity, taxonomic distance, and the World Reference Base. Geoderma. 155. 132-139.

Soll Survey StafF, 1999. Soil Taxonomy. A Basic System of Soil Classification for Making and Interpreting Soil Surveys. Agricultural Handbook No. 436. $2^{\text {nd }}$ ed. Natural Resources Conservation Service, USDA. Washington, D. C.

STEFANOVITS P., 1963. Magyarország talajai 2. Bővített, átdolgozott kiadás. Akadémiai Kiadó. Budapest.

Stefanovits P., 1972. Talajtan. Mezőgazda Kiadó. Budapest.

Stefanovits P., 1999. A talajok osztályozása. In: Talajtan. (Stefanovits P., FiLEP Gy. \& FÜLEKY GY.) 239-320. Mezőgazda Kiadó. Budapest.

SzABOLCS I. (Ed.) 1966. A genetikus üzemi talajtérképezés módszerkönyve. OMMI Genetikus Talajtérképek. Ser. 1. No. 9. OMMI. Budapest.

TIM (Talajvédelmi Információs és Monitoring Rendszer), 1995. Módszertan. Földmüvelésügyi Minisztérium Növényvédelmi és Agrár-környezetgazdálkodási Főosztály, Budapest.

VÁRALLYAY, GY. et al., 2010. Soil conditions in Hungary based on the data from the Soil Conservation Information and Monitoring System (SIMS). Ministry of Agriculture and Rural Development. Budapest.

WALTNER I., FuCHS M., LÁNG V. \& MichÉLI E., 2012. Hazai archív talajadatok beillesztésének lehetőségei nemzetközi adatbázisokba. Agrokémia és Talajtan. 61. (2) 263-276.

Érkezett: 2015. február 16. 